\title{
SELECTION OF SUMBA ONGOLE (SO) CATTLE BASED ON BREEDING VALUE AND PERFORMANCE TEST
}

\author{
S. Said ${ }^{1}$, P. P. Agung' ${ }^{1}$, W. P. B. Putra ${ }^{1}$, S. Anwar ${ }^{1}$, A. S. Wulandari ${ }^{1}$ and A. Sudiro $^{2}$ \\ ${ }^{1}$ Laboratory of Animal Reproduction, Breeding and Cell Culture, \\ Indonesian Institute of Sciences, \\ Jln. Raya Jakarta-Bogor Km. 46 Cibinong, Bogor, Jawa Barat 16911-Indonesia \\ ${ }^{2}$ PT. Karya Anugerah Rumpin \\ Jln. Raya Cibodas No. 99 Rumpin, Bogor, Jawa Barat 16350 \\ Corresponding E-mail: syahruddinsaid01@gmail.com
}

Received June 20, 2016; Accepted August 15, 2016

\begin{abstract}
ABSTRAK
Seleksi pada ternak bertujuan untuk meningkatkan produktivitas. Sebanyak 50 ekor sapi Sumba Ongole (SO) terdiri dari 25 jantan dan 25 betina digunakan untuk uji performan. Uji performan pada sapi dilakukan pada tiga periode $(2014,2015$ dan 2016) selama \pm 535 hari. Data rekording berat badan dianalisis secara deskriptif dengan program komputer Microsoft Office Excel 2007. Sapi dengan umur 300 sampai 600 hari dipilih untuk program uji performan. Hasil penelitian menunjukkan bahwa nilai heritabilitas berat setahunan $\left(\mathrm{YW}_{365}\right)$ sebesar $0,77 \pm 0,68$ dan termasuk kategori tinggi. Nilai pemuliaan $\mathrm{YW}_{365}$ tertinggi sebesar $66,05 \mathrm{~kg}$ (jantan) dan 41,89 kg (betina). Rata-rata berat akhir terkoreksi (BAT) terhadap rerata umur sebesar $391,52 \pm 51,88 \mathrm{~kg}$ (jantan) dan $318,29 \pm 51,53 \mathrm{~kg}$ (betina). Hasil uji performan pada penelitian ini diperoleh enam ekor sapi kelas A (1 jantan dan 5 betina) yang memiliki kriteria sesuai dengan standar minimum ukuran tubuh pada sapi SO.

Kata kunci: Sumba Ongole, berat umur setahun, heritabilitas, nilai pemuliaan, uji performan
\end{abstract}

\begin{abstract}
Selection of livestock was purposed to increase productivity. A performance test was conducted using 25 males and 25 females of Sumba Ongole (SO) cattle. The performance test were conducted in three periods $(2014,2015$ and 2016) for about 535 days. Descriptive statistics ws used to analyze data of body weight. Cattle with age between 300 to 600 days were used for evaluation. Result showed that heritability value of yearling weight $\left(\mathrm{YW}_{365}\right)$ was $0.77 \pm 0.68$ as a high category. The highest breeding value of $\mathrm{YW}_{365}$ were $66.05 \mathrm{~kg}$ (male) and $41.89 \mathrm{~kg}$ (female). The average of corrected final weight (CFW) weight were $172.55 \pm 34.22 \mathrm{~kg}$ (male) and $159.80 \pm 37.73 \mathrm{~kg}$ (female). The performance test in this study obtained six A class (1 bull and 5 cows) based on the standard minimum of body measurements for SO cattle.
\end{abstract}

Key words: Sumba Ongole, yearling weight, heritability, breeding value, performance test

\section{INTRODUCTION}

Sumba Ongole (SO) cattle is one of Indonesian indigenous cattle that live in Sumba
Island (Nusa Tenggara Timur Province). The SO cattle was imported from India since 1906 by Dutch colonial government (Hardjosubroto, 1994). This cattle was Bos indicus and adapted 
well at tropical climate and this breed potential as a beef cattle in Indonesia. Agung et al. (2015) reported that the average of hot carcass weight of male SO cattle (slaughters weight $626 \mathrm{~kg}$ to 650 $\mathrm{kg}$ ) was $358.06 \pm 15.35 \mathrm{~kg}$. Meanwhile, Hendro (2010) reported that the average body weight and hot carcass weight of male SO cattle (2.5 to 3.0 years age) at 90 days of fattening reached $444.90 \pm 6.64 \mathrm{~kg}$ and 243.60+3.13 kg, respectively. Priyanto et al. (2015) reported that $\mathrm{pH}$, water holding capacity, tenderness, cooking loss, and marbling score of male SO cattle meat (18 to 30 months of age) are $5.50 \pm 0.07$; $29.09 \pm 1.61 \% \quad \mathrm{mg} \quad \mathrm{H}_{2} \mathrm{O} ; 7.55 \pm 0.64 \mathrm{~kg} / \mathrm{cm}^{2}$; $46.79 \pm 3.06 \%$; and $2.00 \pm 0.26$; respectively. .

Selection for genetic improvement in SO cattle can be reached through progeny test and performance test (Hardjosubroto, 1994). The progeny test was used for bull selection based on offspring performance. Therefore, selection of bull and heifer could be conducted by using the breeding value (BV) information (Falconer and Mackay, 1996). Cattle with highest BV score is the best livestock among their herd. Most of breeding centre in the world using body weight (birth, weaning, yearling weights) and body measurements (withers height, body length, heart girth) as the criteria of livestock selection. Several study showed that yearling weight at 365 days of age $\left(\mathrm{YW}_{365}\right)$ are used as selection criteria in Bali (Supriyantono et al., 2010), Ongole grade/PO (Prihandini et al., 2011), Bhagnari $\mathrm{x}$ Droughtmaster (Khan et al., 1998), Hanwoo (Park et al., 2013) and Nelore cow (Mercadante et al., 2003). The selected bull and heifer must be continued to the performance test as the last selection step in beef cattle (Rodriguez and Guerra, 2013). Patmawati et al. (2013) reported that the performance test for 9 months) in Bali bull (1 to 2 years age) obtained body weight of $261.56 \pm 81.20 \mathrm{~kg}$, withers height of $17.61 \pm 6.40$ $\mathrm{cm}$, body length of $123.08 \pm 10.07 \mathrm{~cm}$ and heart girth of $156.89 \pm 15.15 \mathrm{~cm}$.

As a local cattle, study of selection system in SO cattle at the breeding station is very important to obtain the best bull and cow. The selected bull from the selection program can be used for producing semen through libido and sperm quality tests. Therefore, the semen can be used for genetic improvement of cattle, especially in Sumba Island. The aim of this study was conducted to select the best SO bull and heifer based on performance test during 2014 to 2016 at the breeding station.

\section{MATERIALS AND METHODS}

\section{Research Site and Animals}

This research was conducted at private breeding station (PT. Karya Anugerah Rumpin) in Rumpin district, Bogor Regency, West Java Province. The station is situated at latitude $06^{\circ} 28^{\prime} 50.3$ " $\mathrm{S}$ and longitude 106 $39^{\circ} 03.0^{\prime \prime} \mathrm{E}$ about 3500 to $4000 \mathrm{~m}$ above the sea level. The humidity $70 \%$ to $80 \%$ with temperature $28^{\circ} \mathrm{C}$ to $30^{\circ} \mathrm{C}$ and rainfall occuring $\pm 2,500 \mathrm{~mm} /$ year. Records data of body weight from sixty SO cattle (year 2012 to 2016) were used in the study.

\section{Animals Management}

The animals were devided into two groups based on sex at the colony stall. Three periods of performance test were conducted in this study (Table 1). Cattle with 300 to 600 days of age with individual breeding value (BV) of yearling weight at 365 days of age were used for evaluation. Cattle were adapted to a ration for two month before the test. The ration consisted of Elephant grass (Pennisetum purpureum), rice straw and cassava meal. They were fed the ration ad libitum $60 \%$ and $40 \%$ of the energy approximately were provided by silage and concentrate, respectively. The nutrient compostion for $\mathrm{SO}$ cattle at the breeding station presented in Table 2 .

\section{Animal Measurements}

The cattle were weighed and measured every month since birth to final age using digital weight scale and calipers respectively. The WH was measured with a stick-ruler as the distance from the surface of the platform to the dorsal point ( $O s$ vertebrae thoracalis $I I I$ ) of the withers. The $\mathrm{BL}$ was measured using a tape from the distance between the point of the shoulder (Tuber humerus on Os humerus) and the pinbone (Tuber ischiadicum on Os coxa). The HG was measured using a tape measure as circumference of the chest just behind the foreleg (Os costa $V$ ). The SC was measured using a tape measure as circumference of the scrotum.

\section{Data Analysis}

Data Correction. Data of birth, weaning and yearling weights were corrected based on Hardjosubroto (1994):

$\mathrm{CF}_{\text {Sex }}=\frac{\mathrm{BW}_{\text {Male }}}{\mathrm{BW}}$ 
Table 1. The Performance Test Schedule for SO Cattle at Breeding Station

\begin{tabular}{ccrlcc}
\hline Period & Group & N & \multicolumn{2}{c}{ Date of Testing } & Duration \\
\cline { 4 - 5 } & & & \multicolumn{1}{c}{ Start } & Finish & (days) \\
\hline I & Bull & 13 & 10 September 2012 & 13 May 2014 & 609 \\
& Cow & 10 & 20 May 2013 & 24 May 2014 & 369 \\
II & Bull & 5 & 2 February 2014 & 29 July 2015 & 542 \\
& Cow & 7 & 15 February 2014 & 12 May 2015 & 451 \\
III & Bull & 7 & 25 December 2014 & 21 March 2016 & 452 \\
& Cow & 8 & 29 January 2015 & 24 March 2016 & 785 \\
\hline
\end{tabular}

$\mathrm{N}$ : numbert of animal

Where

$\begin{array}{ll}\mathrm{CF}_{\text {Sex }} \quad \begin{array}{l}\text { : correction factor of sex (only used for } \\ \text { female animal) }\end{array} \\ \mathrm{WW}_{205} \quad \begin{array}{l}\text { : corrected weaning weight }(\mathrm{kg}) \text { at } 205 \\ \text { days of age }\end{array} \\ \mathrm{YW}_{365} \quad \begin{array}{l}\text { : corrected yearling weight }(\mathrm{kg}) \text { at } 365 \\ \text { days of age }\end{array} \\ \mathrm{BW} & : \text { birth weight }(\mathrm{kg}) \\ \mathrm{WW} & : \text { actual weaning weight }(\mathrm{kg}) \\ \mathrm{W} & : \text { weight when measured }(\mathrm{kg}) \\ \mathrm{T}_{1} & \begin{array}{l}\text { : interval time (days) between birth to } \\ \text { weaning measurement }\end{array} \\ \mathrm{T}_{2} & : \text { interval time (days) between weaning } \\ & \text { to measurement }\end{array}$

Heritability. Estimation of heritability value was calculated using analysis of variance (ANOVA) method with Patternal Halfshib Correlation model refering to Becker (1992):

$\mathrm{h}^{2}=4 \mathrm{t}$

$\mathrm{t}=\frac{\operatorname{Var}_{(\mathrm{S})}}{\operatorname{Var}_{(\mathrm{S})}+\operatorname{Var}_{(\mathrm{w})}}$

$\mathrm{SE}\left(\mathrm{h}^{2}\right)=4 \sqrt{\frac{2(1-\mathrm{t})^{2}[1+(\mathrm{k}-1)(\mathrm{t})]^{2}}{\mathrm{k}(\mathrm{k}-1)(\mathrm{S}-1)}}$

$\mathrm{k}=\frac{1}{\mathrm{~S}-1}\left(\mathrm{~N}-\frac{\sum \mathrm{n}_{\mathrm{i}}^{2}}{\mathrm{~N}}\right)$

Where

$\mathrm{h}^{2} \quad$ : heritability

$$
\begin{array}{ll}
\operatorname{Var}_{(\mathrm{S})} & : \text { variance of sire } \\
\operatorname{Var}_{(\mathrm{W})} & : \text { variance of individu } \\
\operatorname{Cov}_{(\mathrm{S})} & : \text { covariance of sire } \\
\mathrm{SE} & : \text { standard error } \\
\mathrm{k} & : \text { constanta } \\
\mathrm{S} & : \text { number of sire } \\
\mathrm{N} & : \text { total of progeny } \\
\mathrm{n}_{\mathrm{i}} & : \text { number of progeny per sire }
\end{array}
$$

Breeding value. Estimation of breeding value (BV) for each animal was conducted to yearling weight $\left(\mathrm{YW}_{365}\right)$ and calculated based on Hardjosubroto (1994):

$\mathrm{BV}=\mathrm{h}^{2}\left(\mathrm{P}_{\text {Ind. }}-\mathrm{P}_{\mathrm{Pop}}\right)+\mathrm{P}_{\mathrm{Pop}}$

Where

BV : breeding value

$\mathrm{h}^{2} \quad$ : heritability

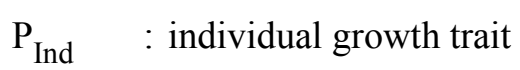

$\mathrm{P}_{\text {Pop }} \quad$ : average of growth trait in population

Performance test. Records data of body weight were analysed descriptely using Microsoft Office Excel 2007 computer program and referring to Hardjosubroto (1994):

$\mathrm{CIW}=\left(\frac{\mathrm{IW}-\mathrm{BW}}{\mathrm{Age}} \times \overline{\mathrm{X}}_{\mathrm{Age}}\right)+\mathrm{BW}$

$\mathrm{WG}=\mathrm{AFW}-\mathrm{IW}$

$\mathrm{CFW}=\mathrm{CIW}+\mathrm{WG}$ 
Where

CIW : corrected initial weight $(\mathrm{kg})$

CFW : corrected final weight $(\mathrm{kg})$

IW : initial weight before performance test $(\mathrm{kg})$

AFW : actual final weight after performance test $(\mathrm{kg})$

WG : weight gain $(\mathrm{kg})$

BW : birth weight $(\mathrm{kg})$

Age : age at end of test

$\overline{\mathrm{X}}_{\text {Age }}$ : average of age at end of the test (days)

Data of body measurements of cattle were compared to Indonesian National Standard (SNI) of minimum body measurements for SO cattle number, Indonesia National Standard (ISN): 7651.7:2016 (Table 3).

\section{RESULT AND DISCUSSION}

\section{Body Weight}

Birth weight. Table 4 shows the descriptive statistics of age and body weight at initial of the performance test in SO cattle. The BW of SO cattle was higher than other Indonesian native cattle such as Bali $(17.80 \pm 1.08 \mathrm{~kg})$, Madura $(15.74 \pm 2.62 \mathrm{~kg})$, Ongole grade/PO $(26.10 \pm 1.55$ $\mathrm{kg}$ ) and $13.52 \pm 1.74 \mathrm{~kg}$ for Aceh (Kaswati et al., 2013; Yusran et al., 1995; Paputungan et al., 2015; Putra et al., 2014). Therefore, the average of BW was similar to other Bos indicus breeds such as Brahman cross $(31.33 \pm 3.52 \mathrm{~kg})$, Nellore $(32.30 \pm 3.80 \mathrm{~kg})$, Red Chittagong $(16.74 \pm 0.36 \mathrm{~kg})$ and $20.00 \pm 4.96 \mathrm{~kg}$ for Malawi Zebu (Muslim et

Table 2. Feed Nutrient Standard for SO Cattle at the Breeding Station (100\% DM)

\begin{tabular}{lrrr}
\hline \multicolumn{1}{c}{ Nutrient } & Quality 1 & Quality 2 & Quality 3 \\
\hline Macro & & & \\
Dry matter (\%) & 82.59 & 83.21 & 86.11 \\
Crude protein (\%) & 7.61 & 12.44 & 12.73 \\
Crude fat (\%) & 4.41 & 5.90 & 5.23 \\
Crude fiber (\%) & 16.35 & 13.80 & 14.91 \\
TDN (\%) & 59.00 & 64.72 & 68.87 \\
ME Mcal (\%) & 1.71 & 1.96 & 2.32 \\
Starch (\%) & 31.74 & 29.42 & 32.69 \\
Lignin (\%) & 4.92 & 3.59 & 3.99 \\
Minerals & & & \\
Ca (\%) & 1.55 & 2.06 & 0.73 \\
P (\%) & 0.44 & 0.64 & 0.40 \\
Mg (\%) & 0.10 & 0.12 & 0.15 \\
K (\%) & 0.56 & 0.59 & 0.66 \\
Na (\%) & 0.07 & 0.10 & 0.04 \\
Fe (ppm) & 48.06 & 563.32 \\
Zn (ppm) & 14.61 & 24.01 & 19.51 \\
Cu (ppm) & 6.07 & 6.89 & 71.36 \\
Mn (ppm) & 44.72 & 51.64 & 0.17 \\
Mo (ppm) & 0.12 & 0.24 & 0.28 \\
S (\%) & 0.11 & 0.15 & 0.00 \\
Cl (\%) & 0.00 & 0.05 & 0.00 \\
Co (\%) & 0.12 & 0.00 &
\end{tabular}


Table 3. Indonesian National Standard (INS) of Minimum Body Measurements for SO Cattle at 24 to 30 Months of Age

\begin{tabular}{rlrrr}
\hline Sex & \multicolumn{1}{c}{ Measurements $(\mathrm{cm})$} & Class A & Class B & Class C \\
\hline \multirow{3}{*}{ Male } & Withers height & 147 & 140 & 133 \\
& Body length & 145 & 138 & 131 \\
& Heart girth & 179 & 172 & 165 \\
& Scrotal circumferance & 28 & 28 & 28 \\
\multirow{5}{*}{ Female } & Withers height & 132 & 127 & 122 \\
& Body length & 131 & 126 & 121 \\
& Heart girth & 165 & 160 & 155 \\
\hline
\end{tabular}

Source: Directorate General of Livestock and Animal Health of Indonesia.

al., 2011; Tatiane et al., 2014; Rabeya et al., 2009; Nandolo et al., 2016). Meanwhile, the average of BW in Bos taurus group such as Friesian Holstein $(33.90 \pm 0.90 \mathrm{~kg})$, Angus $(35.40 \pm 3.80 \mathrm{~kg})$, Hereford $(35.20 \pm 4.60 \mathrm{~kg})$ and $49.20 \pm 7.10 \mathrm{~kg}$ for Belgian Blue (Ozkaya, 2013; Nugent et al., 1991; Kolkman et al., 2010). The average of $\mathrm{BW}$ in Bos taurus breed was higher than Bos indicus. A diversity in genetic, management and environment of animal may cause these differences.

Weaning weight. The average of weaning weight $\left(\mathrm{WW}_{205}\right)$ in SO cattle in this study is presented in Table 4. The $\mathrm{WW}_{205}$ in several Indonesian native cattle are Bali $(88.59 \pm 16.15$ $\mathrm{kg})$, Brahman cross $(107.13 \pm 19.25 \mathrm{~kg})$, PO $(109.10 \pm 18.35 \mathrm{~kg})$ and $44.68 \pm 11.00 \mathrm{~kg}$ for Aceh (Kaswati et al., 2013; Duma and Tanari, 2008; Prihandini et al., 2011; Putra et al., 2014). The weaning weight of Indonesian native cattle (Bali and SO) are lower than African native cattle such as Bonsmara $(215.00 \pm 10.90 \mathrm{~kg})$ and Tuli $(144.00 \pm 5.00 \mathrm{~kg})$ as reported by Rakwadi et al. (2014). Weaning weight (6 months) of Red Chittagong are $43.20 \pm 1.40 \mathrm{~kg}$ (male) and $41.90 \pm 1.30 \mathrm{~kg}$ for female (Afroz et al., 2011) and lower than SO cattle. The weaning weight of female SO cattle in this study was higher than Bhagnari cattle $(99.75 \pm 4.66 \mathrm{~kg})$ and Droughtmaster $\mathrm{x}$ Bhagnari $(105.47 \pm 2.02 \mathrm{~kg})$ as reported by Waheed et al. (2003). The weaning weight of Nellore and Indubrazuil cattle were $185.00 \pm 29.20 \mathrm{~kg}$ and $182.53 \pm 30.00 \mathrm{~kg}$, respectively (Tatiane et al., 2014; Rios-Utrera et al., 2013)
Yearling weight. The average of yearling weight $\left(\mathrm{YW}_{365}\right)$ in SO cattle in this study was presented in Table 4. The average of $\mathrm{YW}_{365}$ in several Indonesian native cattle such as Bali, Brahman cross, PO, and Aceh are 131.12 \pm 25.50 ; $254.32 \pm 47.91 ; 132.70 \pm 19.93$; and $67.02 \pm 17.44$ kg; respectively (Kaswati et al., 2013; Duma and Tanari, 2008; Prihandini et al., 2011; Putra et al., 2014). The $\mathrm{YW}_{365}$ of SO cattle in this study was higher than other Indonesian native cattle at the previous studies. Assan and Nyoni (2009) reported that the yearling weight of Tuli cattle were $180.89 \pm 1.73$ and $161.29 \pm 1.59$. Afroz et al., 2011 reported that the average of $\mathrm{YW}_{365}$ in Red Chittagong cattle are $64.00 \pm 3.30$ and $68.40 \pm 3.20$ $\mathrm{kg}$ for male and female, respectively. The body weight at 365 days of age was the important for bull and heifer selection (Prihandini et al., 2011). Mercadante et al. (2011) reported that selection of Nelore cow based on yearling weight could be increased the weight at 550 days of age. Meanwhile, the average of yearling weight in Nellore cattle are $268.09 \pm 39.47 \mathrm{~kg}$ (Regatieri et al., 2012).

Initial Weigh. Table 5 shows the descriptive statistic of age, body weight and weight gain at end of the performance test in SO cattle. Nahar et al. (2016) reported that the average of initial weight (IW) in Red Red Chittagong were $63.02 \pm 1.48$ and $70.74 \pm 2.02 \mathrm{~kg}$, respectively for male (360 days of age) and female (450 days of age) at about 1.5 years period of the test. Mashiloane et al. (2012) also maintained the initial age (IA) for Bonsmara and Nguni bulls about $355.50 \pm 30.91$ days and $371.20 \pm 33.76$ days, 
Table 4. Descriptive Statistics of Age and Body Weight at Entrance of the Performance Test in SO Cattle

\begin{tabular}{|c|c|c|c|c|c|c|}
\hline \multirow{2}{*}{ Period } & \multirow{2}{*}{ Group / Performance } & \multicolumn{5}{|c|}{ Parameters } \\
\hline & & Mean & SD & $\mathrm{CV}(\%)$ & Min. & Max. \\
\hline \multirow{12}{*}{ I } & Bull $(\mathrm{N}=13)$ & & & & & \\
\hline & Age (days) & 392.23 & 85.68 & 21.84 & 300.00 & 528.00 \\
\hline & Birth weight $(\mathrm{kg})$ & 26.77 & 1.36 & 5.09 & 25.00 & 30.00 \\
\hline & $\mathrm{WW}_{205}(\mathrm{~kg})$ & 113.67 & 25.24 & 22.47 & 45.64 & 143.82 \\
\hline & $\mathrm{YW}_{365}(\mathrm{~kg})$ & 164.65 & 37.17 & 22.58 & 118.02 & 252.59 \\
\hline & Initial weight (kg) & 181.23 & 28.49 & 15.72 & 142.00 & 248.00 \\
\hline & $\operatorname{Cow}(\mathrm{N}=10)$ & & & & & \\
\hline & Age (days) & 386.10 & 43.63 & 11.30 & 319.00 & 473.00 \\
\hline & Birth weight (kg) & 30.88 & 2.36 & 7.63 & 28.00 & 36.00 \\
\hline & $\mathrm{WW}_{205}(\mathrm{~kg})$ & 83.82 & 31.39 & 37.45 & 48.31 & 144.15 \\
\hline & $\mathrm{YW}_{365}(\mathrm{~kg})$ & 197.62 & 17.32 & 8.77 & 176.17 & 221.21 \\
\hline & Initial weight (kg) & 138.80 & 44.05 & 31.74 & 91.00 & 221.00 \\
\hline \multirow{12}{*}{ II } & Bull $(\mathrm{N}=5)$ & & & & & \\
\hline & Age (days) & 432.00 & 116.64 & 27.00 & 323.00 & 575.00 \\
\hline & Birth weight $(\mathrm{kg})$ & 23.00 & 8.37 & 36.38 & 10.00 & 30.00 \\
\hline & $\mathrm{WW}_{205}(\mathrm{~kg})$ & 94.76 & 20.31 & 21.43 & 65.22 & 114.78 \\
\hline & $\mathrm{YW}_{365}(\mathrm{~kg})$ & 164.77 & 16.55 & 10.04 & 140.63 & 180.96 \\
\hline & Initial weight (kg) & 192.00 & 50.59 & 26.35 & 149.00 & 251.00 \\
\hline & Cow $(N=7)$ & & & & & \\
\hline & Age (days) & 593.29 & 32.15 & 5.42 & 551.00 & 636.00 \\
\hline & Birth weight (kg) & 21.86 & 3.02 & 13.83 & 16.00 & 25.00 \\
\hline & $\mathrm{WW}_{205}(\mathrm{~kg})$ & 106.40 & 14.47 & 13.60 & 89.33 & 128.44 \\
\hline & $\mathrm{YW}_{365}(\mathrm{~kg})$ & 160.20 & 25.48 & 15.90 & 130.57 & 200.04 \\
\hline & Initial weight (kg) & 159.43 & 27.66 & 17.35 & 126.00 & 205.00 \\
\hline \multirow{12}{*}{ III } & Bull $(\mathrm{N}=7)$ & & & & & \\
\hline & Age (days) & 365.67 & 74.90 & 20.48 & 318.00 & 452.00 \\
\hline & Birth weight (kg) & 22.00 & 5.83 & 26.50 & 15.00 & 32.00 \\
\hline & $\mathrm{WW}_{205}(\mathrm{~kg})$ & 103.93 & 37.76 & 36.33 & 62.30 & 163.19 \\
\hline & $\mathrm{YW}_{365}(\mathrm{~kg})$ & 143.97 & 29.81 & 20.71 & 107.93 & 187.38 \\
\hline & Initial weight (kg) & 144.43 & 23.59 & 16.33 & 113.00 & 178.00 \\
\hline & Cow $(\mathrm{N}=8)$ & & & & & \\
\hline & Age (days) & 384.00 & 112.23 & 29.23 & 309.00 & 646.00 \\
\hline & Birth weight $(\mathrm{kg})$ & 21.75 & 3.88 & 17.85 & 15.00 & 25.00 \\
\hline & $\mathrm{WW}_{205}(\mathrm{~kg})$ & 112.83 & 17.03 & 15.10 & 91.94 & 138.15 \\
\hline & $\mathrm{YW}_{365}(\mathrm{~kg})$ & 158.83 & 31.60 & 19.90 & 102.59 & 215.99 \\
\hline & Initial weight (kg) & 169.25 & 40.37 & 23.85 & 126.00 & 253.00 \\
\hline
\end{tabular}

$\mathrm{N}=$ number of observation; $\mathrm{SD}=$ standard deviation; $\mathrm{CV}=$ coefficient of variation; Min.= minimum value; Max.= maximum value; $\mathrm{WW}_{205}=$ weaning weight at 205 days of age; $\mathrm{YW}_{365}=$ yearling weight at 365 days of age 
Table 5. Descriptive Statistic of Age, Body Weight and Weight Gain at End of the Performance Test in SO Cattle

\begin{tabular}{|c|c|c|c|c|c|c|}
\hline \multirow{2}{*}{ Period } & \multirow{2}{*}{ Group / Performance } & \multicolumn{5}{|c|}{ Parameters } \\
\hline & & Mean & SD & $\mathrm{CV}(\%)$ & Min. & Max. \\
\hline \multirow{12}{*}{ I } & Bull $(\mathrm{N}=13)$ & & & & & \\
\hline & Age (days) & 1005.69 & 83.98 & 8.35 & 910.00 & 1138.00 \\
\hline & CIW (kg) & 181.05 & 25.59 & 14.14 & 154.09 & 257.36 \\
\hline & CFW (kg) & 473.90 & 24.13 & 5.09 & 438.35 & 508.81 \\
\hline & $\mathrm{AFW}(\mathrm{kg})$ & 474.08 & 25.98 & 5.48 & 433.00 & 529.00 \\
\hline & WG (kg) & 292.85 & 43.52 & 14.86 & 185.00 & 350.00 \\
\hline & $\operatorname{Cow}(\mathrm{N}=10)$ & & & & & \\
\hline & Age (days) & 759.80 & 42.09 & 5.54 & 688.00 & 842.00 \\
\hline & CIW (kg) & 140.03 & 49.03 & 35.01 & 89.99 & 243.11 \\
\hline & CFW (kg) & 317.33 & 50.23 & 15.83 & 254.30 & 396.73 \\
\hline & $\mathrm{AFW}(\mathrm{kg})$ & 316.10 & 50.78 & 16.06 & 256.00 & 400.00 \\
\hline & WG (kg) & 177.30 & 66.19 & 37.33 & 81.00 & 297.00 \\
\hline \multirow{12}{*}{ II } & $\operatorname{Bull}(\mathrm{N}=5)$ & & & & & \\
\hline & Age (days) & 785.40 & 72.10 & 9.18 & 684.00 & 853.00 \\
\hline & CIW (kg) & 194.25 & 54.85 & 28.23 & 139.31 & 262.87 \\
\hline & CFW (kg) & 343.05 & 51.35 & 14.97 & 262.20 & 389.38 \\
\hline & $\mathrm{AFW}(\mathrm{kg})$ & 340.80 & 62.64 & 18.38 & 241.00 & 400.00 \\
\hline & WG (kg) & 148.80 & 79.10 & 53.16 & 82.00 & 236.00 \\
\hline & Cow $(\mathrm{N}=7)$ & & & & & \\
\hline & Age (days) & 802.00 & 31.92 & 3.98 & 760.00 & 845.00 \\
\hline & CIW (kg) & 158.83 & 23.58 & 14.85 & 131.16 & 200.41 \\
\hline & CFW (kg) & 353.26 & 63.52 & 17.98 & 234.16 & 440. \\
\hline & $\mathrm{AFW}(\mathrm{kg})$ & 353.86 & 67.40 & 19.05 & 229.00 & 445.00 \\
\hline & WG (kg) & 194.43 & 43.63 & 22.44 & 103.00 & 240.00 \\
\hline \multirow{12}{*}{ III } & Bull $(\mathrm{N}=7)$ & & & & & \\
\hline & Age (days) & 977.67 & 122.68 & 12.55 & 838.00 & 1068.00 \\
\hline & CIW (kg) & 146.88 & 25.31 & 17.23 & 110.41 & 185.45 \\
\hline & CFW (kg) & 357.60 & 80.15 & 22.41 & 262.00 & 480.41 \\
\hline & $\mathrm{AFW}(\mathrm{kg})$ & 355.14 & 87.41 & 24.61 & 243.00 & 489.00 \\
\hline & WG (kg) & 210.71 & 92.53 & 43.91 & 109.00 & 370.00 \\
\hline & Cow $(\mathrm{N}=8)$ & & & & & \\
\hline & Age (days) & 870.63 & 172.01 & 19.76 & 695.00 & 1076.00 \\
\hline & CIW (kg) & 160.07 & 40.15 & 25.08 & 99.30 & 220.90 \\
\hline & CFW (kg) & 294.07 & 37.43 & 12.73 & 242.14 & 344.90 \\
\hline & $\mathrm{AFW}(\mathrm{kg})$ & 303.25 & 49.57 & 16.34 & 230.00 & 374.00 \\
\hline & WG (kg) & 134.00 & 48.07 & 35.87 & 86.00 & 233.00 \\
\hline
\end{tabular}

$\mathrm{N}=$ number of observation; $\mathrm{SD}=$ standard deviation; $\mathrm{CV}=$ coefficient of variation; Min. $=$ minimum value; Max.= maximum value; $\mathrm{CIW}=$ corrected initial weight $\mathrm{CFW}=$ corrected final weight; $\mathrm{AFW}=$ actual final weight; $\mathrm{WG}=$ weight gain 
respectively. Therefore, the IW in the performance test were $251.91 \pm 34.14 \mathrm{~kg}$ (Bonswana) and $180.54 \pm 33.76 \mathrm{~kg}$ (Nguni). Oikawa et al. (2006) reported that the average of IW and IA in Japanese Black bull at 112 days period of the test were $260.80 \pm 32.70 \mathrm{~kg}$ and $231.40 \pm 18.50 \mathrm{~kg}$, respectively. The effective duration of performance test in cattle about 12 months with IW about 600 days of age (Hardjosubroto, 1994).

Final Weight. The average of AFW in SO cattle is presented in Table 5. Nahar et al. (2016) reported that the average AFW of Red Chittagong

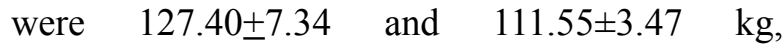
respectively for male (900 days of age) and female (810 days of age). Mashiloane et al. (2011) obtained the AFW of Bonsmara and Nguni were $389.71 \pm 29.21304 .33 \pm 27.23 \mathrm{~kg}$, respectively during one year of the test period. Reis et al. (2013) reported that the AFW in Nellore young bulls were 279.30 to $330.00 \mathrm{~kg}$ with average of IW about 243.00 to $245.90 \mathrm{~kg}$ at the 3 months of test period in grassland. Garcia et al. (2005) obtained the performance test for Bos taurus breeds (Angus, Charolais and Hereford) with IW about $300 \mathrm{~kg}$ could be reached respective AFW and $W G$ about $500 \mathrm{~kg}$ and $1.65 \mathrm{~kg} /$ day at one year of the test period. Oikawa et al. (2006) obtained the average of AFW about $392.00 \pm 39.40 \mathrm{~kg}$ with final age about $231.40 \pm 18.50$ days in Japanese Black bull. The AFW and test period in SO cattle in this study was higher than Bonswana, Nguni and Japanese Black at from the result of previous study. Long period of the test ( \pm 535 days) caused may cause a higher final weight and age. However, the age at end of the test for bull was about 1000 days (adult weight)

\section{Genetic Parameters}

Heritability. Table 6 shows the variance components for estimated heritability $\left(\mathrm{h}^{2}\right)$ of $\mathrm{YW}_{365}$. The $h^{2}$ value of $\mathrm{YW}_{365}$ in SO cattle could be the high category $\left(\mathrm{h}^{2}>0.30\right)$ with low standard error. A lower of SE than $h^{2}$ values suggested that this $\mathrm{h}^{2}$ value was accurate for selection criterion (Warwick et al., 1989). Selection of SO cattle could be conducted based on $\mathrm{YW}_{365}$. High heritability value of $\mathrm{YW}_{365}$ were obtained in several Indonesian beef cattle such as Bali, Brahman cross, Simmental and Aceh are $0.54 \pm 0.32 ; 0.44 \pm 0.14 ; 0.43 \pm 0.19$; and $0.49 \pm 0.59$; respectively (Kaswati et al., 2013; Duma and Tanari, 2008; Suhada et al., 2009; Putra et al.,
2014). Previous studies showed that the heritability value of $\mathrm{YW}_{365}$ in several cattle breeds such as Red Chittagong, Tuli, Nguni, Golpayeganian, Bhagnari x Droughtmaster, Nellore and South African Limousin were $0.50 \pm 0.10 ; \quad 0.18 \pm 0.001 ; \quad 0.25 ; \quad 0.48 \pm 0.07$; $0.19 \pm 0.24 ; \quad 0.36 \pm 0.01 ; \quad$ and $0.16 \pm 0.03$; respectively (Afroz et al., 2011; Assan and Nyoni, 2009; Norris et al., 2004; Khan et al., 1998; Regatieri et al., 2012; Niekerk and Neser, 2006)..

Estimated Breeding Value. Table 7 shows the top ten of SO cattle based on breeding value of yearling weight $\left(\mathrm{BV}_{365}\right)$. The highest $\mathrm{BV}_{365}$ in bull and heifer in this study were $66.05 \mathrm{~kg}$ (ID: KBO175) and $41.89 \mathrm{~kg}$ (ID: KAR2091), respectively. Previous study showed that the higher $\mathrm{BV}_{365}$ in $\mathrm{PO}$ and Bali were $5.54 \mathrm{~kg}$ and $20.75 \mathrm{~kg}$, respectively (Prihandini et al., 2011; Supriyantono et al., 2010). Rodriguez and Guerra (2013) obtained $30.40 \mathrm{~kg}$ of the BV for adult weight in Nellore. This research showed that total of 30 selected cattle (15 males and 15 females) from all test periods as presented in Table 8 . Amount of six males (40\%) and 11 females (73\%) from both sex groups having positive BV value. Positive BV value must be used for livestock selection because this value indicates the individual performance from their herd.

\section{Body Measurements and Groups}

Table 9 shows the descriptive statistic of body measurements in SO catle from the

Table 6. Heritability estimation of yearling weight at 365 days of age in SO cattle

\begin{tabular}{|c|c|}
\hline Component & Value \\
\hline $\mathrm{N}_{\mathrm{S}}$ & 5 \\
\hline $\mathrm{N}_{\mathrm{P}}$ & 47 \\
\hline $\operatorname{Var}_{(\mathrm{S})}$ & 148.16 \\
\hline $\operatorname{Var}_{(\mathrm{W})}$ & 620.64 \\
\hline $\mathrm{k}$ & 9 \\
\hline $\mathrm{h}^{2}$ & 0.77 \\
\hline SE & 0.68 \\
\hline
\end{tabular}

$\mathrm{N}_{\mathrm{S}}=$ total of sire; $\mathrm{N}_{\mathrm{P}}=$ total of progeny for estimation; $\mathrm{c}=$ constanta; $\mathrm{h}^{2}=$ heritability; $\mathrm{SE}=$ standard error; $\operatorname{Var}_{(\mathrm{S})}=$ variance of sire; $\operatorname{Var}_{(\mathrm{W})}=$ variance of individu 
Table 7. Top Ten of SO Cattle in the Performance Test Based on Breeding Value of Yearling Weight at 365 Days of Age

\begin{tabular}{|c|c|c|c|c|c|c|c|}
\hline Rank & Catttle ID & Sire & Dam & $\mathrm{BW}$ & $\mathrm{WW}_{205}$ & $\mathrm{YW}_{365}$ & $\mathrm{BV}_{365}$ \\
\hline \multicolumn{8}{|c|}{ Male } \\
\hline 1 & KBO175 & 1999 & 11882 & 26 & 143.82 & 252.59 & 66.05 \\
\hline 2 & KBO174 & 1999 & 0338 & 27 & 137.75 & 200.87 & 26.23 \\
\hline 3 & 3221 & 1129 & 0418 & 25 & 136.47 & 187.38 & 15.84 \\
\hline 4 & KBO170 & 1999 & 11910 & 27 & 128.46 & 185.96 & 14.75 \\
\hline 5 & KBO186 & 11936 & 11825 & 30 & 130.27 & 184.66 & 13.74 \\
\hline 6 & KBO167 & 1999 & 11843 & 26 & 135.52 & 182.50 & 12.08 \\
\hline 7 & 2137 & 1999 & 0822 & 30 & 114.78 & 180.96 & 10.89 \\
\hline 8 & 2908 & 1999 & 11925 & 30 & 112.00 & 176.00 & 7.08 \\
\hline 9 & 2934 & 1976 & 1152 & 20 & 95.88 & 170.86 & 3.11 \\
\hline 10 & 2924 & 2104 & B0793 & 20 & 163.19 & 166.47 & -0.26 \\
\hline \multicolumn{8}{|c|}{ Female } \\
\hline 1 & KAR2091 & 008843 & 0864 & 25 & 84.02 & 221.21 & 41.89 \\
\hline 2 & KAR2095 & 20244 & 0593 & 30 & 77.05 & 221.12 & 41.82 \\
\hline 3 & 3274 & 1976 & 1322 & 25 & 138.15 & 215.99 & 37.87 \\
\hline 4 & KAR2102 & 08843 & 0824 & 30 & 135.70 & 210.22 & 33.43 \\
\hline 5 & KAR2101 & 008843 & 0823 & 30 & 144.15 & 207.28 & 31.16 \\
\hline 6 & KAR2099 & 20244 & 0908 & 36 & 74.25 & 205.22 & 29.27 \\
\hline 7 & 3470 & 1129 & 0820 & 25 & 121.38 & 200.04 & 25.58 \\
\hline 8 & KAR2096 & 008843 & 0860 & 28 & 73.97 & 188.55 & 16.74 \\
\hline 9 & KAR2097 & 20244 & 10277 & 30 & 76.38 & 184.65 & 13.74 \\
\hline 10 & KAR2098 & 012075 & 0742 & 31 & 66.93 & 183.53 & 12.87 \\
\hline
\end{tabular}

$\mathrm{BW}=$ birth weight; $\mathrm{WW}_{205}=$ weaning weight at 205 days of age; $\mathrm{YW}_{365}=$ yearling weight at 365 days of age; $\mathrm{BV}_{365}=$ breeding value of yearling ( 365 days of age) weight

performance test. The average of $\mathrm{WH}, \mathrm{BL}, \mathrm{HG}$ and SC in SO bulls were 138.08 \pm 9.74 , $143.32 \pm 8.12,179.44 \pm 14.32$ and $29.80 \pm 3.51 \mathrm{~cm}$, respectively. Therefore, the average of $\mathrm{WH}, \mathrm{BL}$ and $\mathrm{HG}$ in $\mathrm{SO}$ cows were $128.00 \pm 6.73 \mathrm{~cm}$, $136.14 \pm 7.71 \mathrm{~cm}$ and $167.51 \pm 9.58 \mathrm{~cm}$, respectively. Previous study showed that the average $\mathrm{WH}, \mathrm{BL}$ and $\mathrm{HG}$ in Bali bull from the 270 days of test were $117.61 \pm 6.40,123.08 \pm 10.07$ and $156.89 \pm 15.15 \mathrm{~cm}$, respectively. Research showed that only one bull (KB0174) and five cows (KAR2093, KAR2098, KAR2091, KAR2101 and 3441) were grouped into class A. Four bulls from period I (KBO170, KBO174, 2934, 2908) were recommended for breeding bull at the breeding station. Each selected bull could be used for breeding program at the breeding station.

All bulls at second period of the test were not included in the class group because of lower measurements than INS (Table 2), especially for WH. Meanwhile, only one bull at third period of test could be included into class C (Bull ID: 2986). It was concluded that the best duration test for bull was about 600 days (Period I) with age at initial of the test about 400 days. Meanwhile, the AFW of bull reached about 1000 days ( \pm 3 years). Most of bulls from second test period were not grouped into any class groups because of the lower of WH than INS. However, genetic 


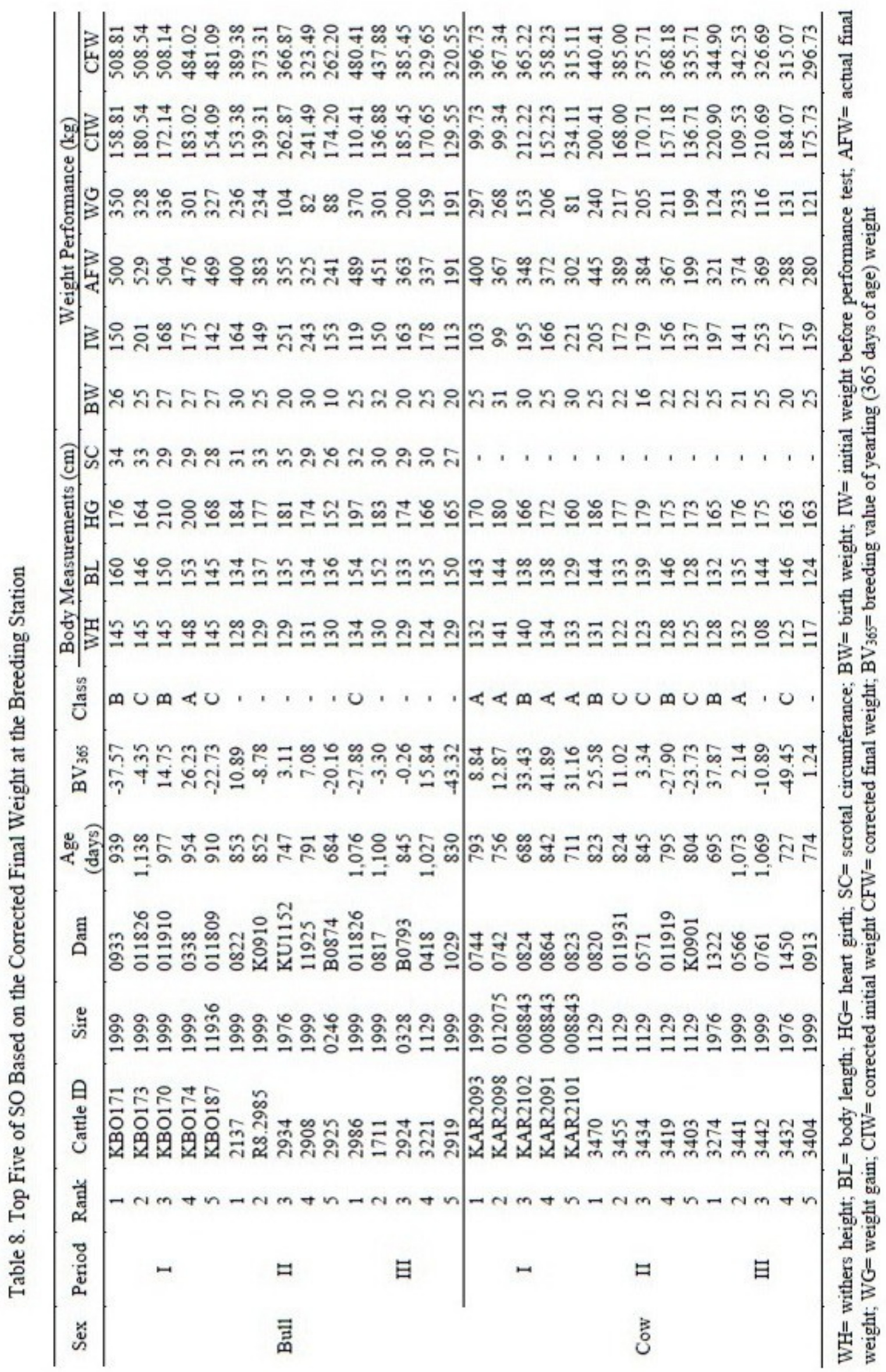


Table 9. Descriptive Statistic of Body Measurements in SO Cattle at End of the Performance Test

\begin{tabular}{|c|c|c|c|c|c|c|}
\hline \multirow{2}{*}{ Period } & \multirow{2}{*}{$\begin{array}{c}\text { Group / } \\
\text { Measurements }(\mathrm{cm})\end{array}$} & \multicolumn{5}{|c|}{ Parameters } \\
\hline & & Mean & SD & $\mathrm{CV}(\%)$ & Min. & Max. \\
\hline \multirow{9}{*}{ I } & Bull $(\mathrm{N}=13)$ & & & & & \\
\hline & Withers height & 146.85 & 2.73 & 1.86 & 144.00 & 152.00 \\
\hline & Body length & 147.31 & 6.05 & 4.10 & 140.00 & 160.00 \\
\hline & Heart girth & 185.08 & 13.75 & 7.43 & 164.00 & 210.00 \\
\hline & Scrotal circumferance & 30.46 & 2.63 & 8.65 & 26.00 & 35.00 \\
\hline & Cow $(N=10)$ & & & & & \\
\hline & Withers height & 135.70 & 3.23 & 2.38 & 132.00 & 141.00 \\
\hline & Body length & 137.40 & 5.54 & 4.03 & 129.00 & 144.00 \\
\hline & Heart girth & 166.20 & 6.89 & 4.15 & 158.00 & 180.00 \\
\hline \multirow{9}{*}{ II } & Bull $(\mathrm{N}=5)$ & & & & & \\
\hline & Withers height & 129.40 & 1.14 & 0.88 & 128.00 & 131.00 \\
\hline & Body length & 135.20 & 1.30 & 0.96 & 134.00 & 137.00 \\
\hline & Heart girth & 173.60 & 12.66 & 7.29 & 152.00 & 184.00 \\
\hline & Scrotal circumferance & 30.80 & 3.49 & 11.34 & 26.00 & 35.00 \\
\hline & $\operatorname{Cow}(\mathrm{N}=7)$ & & & & & \\
\hline & Withers height & 125.86 & 3.08 & 2.45 & 122.00 & 131.00 \\
\hline & Body length & 137.86 & 6.15 & 4.46 & 128.00 & 146.00 \\
\hline & Heart girth & 177.43 & 6.68 & 3.76 & 167.00 & 186.00 \\
\hline \multirow{9}{*}{ III } & $\operatorname{Bull}(\mathrm{N}=7)$ & & & & & \\
\hline & Withers height & 128.00 & 3.96 & 3.09 & 122.00 & 134.00 \\
\hline & Body length & 141.71 & 9.86 & 6.96 & 131.00 & 154.00 \\
\hline & Heart girth & 173.14 & 13.85 & 8.00 & 154.00 & 197.00 \\
\hline & Scrotal circumferance & 27.86 & 4.60 & 16.51 & 18.00 & 32.00 \\
\hline & $\operatorname{Cow}(\mathrm{N}=8)$ & & & & & \\
\hline & Withers height & 123.75 & 7.74 & 6.26 & 108.00 & 132.00 \\
\hline & Body length & 135.75 & 7.46 & 5.49 & 124.00 & 146.00 \\
\hline & Heart girth & 164.63 & 9.52 & 5.78 & 148.00 & 176.00 \\
\hline
\end{tabular}

$\mathrm{N}=$ number of observation; $\mathrm{SD}=$ standard deviation; $\mathrm{CV}=$ coefficient of variation; Min. $=$ minimum value; Max. $=$ maximum value

improvement of $\mathrm{WH}$ in $\mathrm{SO}$ could be increased through selection program. Top five bulls from the first test period could be used as breeding bull at the breeding station. The duration test and age at entrance of the test were the two important factors determining the cattle according to INS.

\section{CONCLUSION}

Livestock selection could be maintained based on breeding value (BV) and continued with the performance test. However, study for economic traits such as feed convertion ratio and 
feed intake in the performance test were further needed for genetic improvement in livestock.

\section{ACKNOWLEDGMENTS}

This research funding was supported partly by Ministry of Research, Technology, and Higher Education, the Republic of Indonesia. A sincere appreciation is expressed to Head of Research Center for Biotechnology, Indonesian Institute of Sciences and Director of PT. Karya Anugerah Rumpin and all staff by permission to use farm facilities. Author gratitude is also expressed to members of Animal Research Group in Research Center for Biotechnology, Indonesian Institute of Sciences.

\section{REFERENCES}

Afroz, M.A., M.A. Haque and A.K.F.H. Bhuiyan. 2011. Estimation of heritability for growth traits of Red Chittagong cattle in a nucleus herd. The Bangladesh Veterinarian. 28(1): 39-46.

Agung, P.P., S. Anwar, A.S. Wulandari, A. Sudiro, S. Said and B. Tappa. 2015. The potency of Sumba Ongole (SO) cattle: A study of genetic characterization and carcass productivity. J. Indonesian Trop. Anim. Agric. 40(2):71-78.

Assan, N. and K. Nyoni. 2009. Systematic enviromental influences and variance due to directand maternal effects and trends for yearling weight in cattle. Anim. Res. Int. 6(3): 1086-1092.

Becker, A. 1992. Manual of Quantitative Genetics. 4th Ed. Washington State University, Washington

Duma, Y. and M. Tanari. 2008. Potensi respon seleksi sifat pertumbuhan sapi Brahman cross di ladang ternak Bila River Ranch, Sulawesi Selatan. Prosiding Seminar Nasional Sapi Potong. Palu, 24 November 2008.

Falconer, R.D. and T.F. Mackay. 1996. Introduction to Quantitative Genetics. 4th Ed. Department of Genetics. North Canada University, Prince George

Garcia, M.D., M.G. Thomas, W.R. Parker, V.R. Beauchemin and R.M. Enns. 2005. Evaluation of performance trends in the Tucumcari Bull Test1961 to 2000. Research Report. 754:1-21.

Hardjosubroto, W. 1994. Aplikasi Pemuliabiakan
Ternak di Lapangan. Gramedia Widiasarana Indonesia, Jakarta.

Hendro, W. 2010. Imbangan hijauan dan konsentrat yang berbeda pada penampilan sapi Sumba Ongole yang diberi tiga macam ransum penggemukan Tesis. Institut Pertanian Bogor, Bogor.

Kaswati, Sumadi and N. Ngadiono. 2013. Estimasi nilai heritabilitas berat lahir, berat sapih dan umur satu tahun pada sapi Bali di Balai Pembibitan Ternak Unggul Sapi Bali. Buletin Peternakan. 37(2):74-78.

Khan, M.S., M. Younas and M.A. Khan. 1998. Genetic and phenotypic (co)variance for yearling weight and post-weaning growth traits in Bhagnari x Droughmaster calves. Pak. J. Biol. Sci. 1(3):202-204.

Kolkman, I., G. Opsomer, S. Aerts, G. Hoflack, H. Leavens and D. Lips. 2010. Analysis of body measurements of newborn purebred Belgian Blue calves. Animal. 4(5):661-671.

Mashiloane, L, A. Bothma, K. Madia, J. Sebei and K. Nephawe. 2012. Growth and feed efficiency of range performance tested beef bulls in the arid sweet bushveld of South Africa. J. Anim. Sci. 2(4): 258-264.

Mercadante, M.E.Z., I.U. Packer, A.G. Razook, J.N.S.G. Cryllo and L.A. Figueiredo. 2003. Direct and correlated responses to selection for yearling weight on reproductive performance of Nelore cows. J. Anim. Sci. 81:376-384

Muslim, K.N., N. Hary and S. Trinil. 2011. Hubungan antara berat badan induk dengan berat lahir pedet sapi Brahman cross pada jenis kelamin yang berbeda. Jurnal IlmuIlmu Peternakan. 23(1):18-24.

Nahar, S., A.F.M.F. Islam, M.A. Haque and A.K.F.H. Bhuiyan. 2016. Animal performance of indegenous Red Chittagong cattle of Bangladesh. Acta Scientiarum. 38(2):177-182.

Nandolo, W, N.G. Timothy, and B. Mcloyd. 2016. Phenotypic and genetic parameters of calf growth traits for Malawi Zebu. LRRD. 28(2).

Niekerk, M. and F.W.C. Neser. 2006. Genetic parameters for growth traits in South African Limousin cattle. S. Afr. J. Anim. Sci. 36(5):6-9.

Norris, D., C. Banga, K. Benyi and B.C. Sithole. 2004. Estimation of genetic parameters and variance components for growth traits of Nguni cattle in Limpopo Province, South 
Africa. Trop. Anim. Heal. Prod. 36:801806.

Nugent, R.A., D.R. Notter and W.E. Beal. 1991. Body measurements of newborn calves and relationship of calve shape to sire breeding values for birth weight and calving ease. J. Anim. Sci. 69(6):2413-2421.

Oikawa, T., M.A. Haque, T. Hitomi, K. Suzuki and H. Uchida. 2006. Geneticparameters for traits in performance and progeny tests and their genetic relationships in Japanese Black cattle. Asian-Aust. J. Anim. Sci. 19(5):611-616.

Ozkaya, S. 2013. The prediction of live weight from body measurements on Holstein calves by digital image analysis. J. Agric. Sci. 151:570-576.

Paputungan U, R.N. Lentji and J.K. Hengky. 2015. Calf birth weight prediction accuracy using calf parturition, durability and metric body measurements in Ongole crossbreds heifers. Int. J. Biol. Sci. Appl. 2(1):10-14.

Park, B, T Choi, S. Kim and S.H. Oh. 2013. National genetic evaluation (system) of Hanwoo (Korean native cattle). AsianAust. J. Anim. Sci. 26(2):151-156

Priyanto, R, A.M. Fuah and E.L. Aditia. 2015. Peningkatan produksi dan kualitas dagng sapi lokal melalui penggemukan berbasis serealia pada taraf energi yang berbeda. Jurnal Ilmu Pertanian Indonesia. 20(2): 108-114.

Prihandini, P.W., L. Hakim and V.M.A. Nurgiartiningsih. 2011. Seleksi pejantan berdasarkan nilai pemuliaan pada sapi Peranakan Ongole (PO) di Loka Penelitian Sapi Potong Grati - Pasuruan. J. Ternak Tropika. 12(1):97-107.

Putra, W.P.B., Sumadi and T. Hartatik. 2014. Potensi respon seleksi sifat pertumbuhan sapi Aceh. JITV. 19(4):248-256

Rabeya, T, A.K.F.H. Bhuiyan, M.A. Habib and M.S. Hossain. 2009. Phenotypic and genetic parameters for growth traits in Red Chittagong cattle of Bangladesh. J. Bangladesh. Agril. Univ. 7(2):265-271.

Rakwadi, E., S.J. Nsoso, T.N. Gondwe and J.W. Banda. 2014. Estimates of phenotypic and genetic parameters and responses to selection in growth traits three breef cattle breeds raised under ranch conditions in Botswana. Bots. J. Agric. Appl. Sci. 10(1): $1-10$.

Regatieri, I.C., A.A. Boligon, F. Baldi and L.G.
Albuquerque. 2012. Genetic correlations between mature cow weight and productive and reproductive traits in Nellore cattle. Genet. Mol. Res. 11(3): 2979-2986.

Reis, R.A, A.L.S. Valente, S.M.C. Dos Santos, F.H.M. De Sauza, T.T. Berchielli, A.C. Ruggieri, S.S. Santana and J.M. Serra. 2013. Performance of young Nellore young bulls grazing marundu grass pasture at different heights. Tropical Grasslands. 1:114-116.

Rios-Utrera, A., V.D.H. Hernandez, E.V.A. Manjarrez, J.P.Z. Martinez and J.A.V. Cortes. 2013. Direct and maternal genetic effects for growth traits in Indubrazil cattle. Revista Cientifica. 23(5): 440-447.

Rodriguez, Y. and D. Guerra. 2013. Evidence of genotype-environment interaction for final live weight in the performance test of the Cuban Zebu. Cuban. J. Agric. Sci. 47(1): 13-17.

Suhada, H., Sumadi and N. Ngadiono. 2009. Estimasi parameter genetik sifat produksi sapi Simmental di Balai Pembibitan Ternak Unggul Sapi Potong Padang Mengatas, Sumatera Barat. Buletin Peternakan. 33(1): $1-7$

Supriyantono, A., L. Hakim, Suyadi and Ismudiono. 2010. Evaluasi pejantan sapi Bali berdasarkan sifat pertumbuhan menggunakan metode Animal Model. Seminar Nasional Teknologi Peternakan dan Veteriner. Bogor, 12 Juli 2010.

Tatiane, C.S.C., L.C. Sabrina, E.B. Marcos, D.A.G. Daniela, G.F.G. Diego, B.D.N. Guilherme, O.R. Jaqueline, B.R. Raysildo and M. Danisio. 2014. Genetic analysis for gestation length, birth weight, weaning weight and accumulated productivity in Nellore beef cattle. Livest. Sci. 170: 16-21.

Waheed, A., A.U. Heyder and M.S. Khan. 2003. Genetic and phenotypic evaluation of the growth performance of Bhagnari and Bhagnari x Droughtmaster female calves in Pakistan. Pakistan. Vet. J. 23(3): 134-142.

Warwick, E.J., M. Astuti and W. Hardjosubroto. 1989. Pemuliaan Ternak. Gadjah Mada University Press, Yogyakarta

Yusran, M.A., K. Ma'sum and D.B. Wijono. 1995. Evaluasi nilai pemuliaan calon pejantan donor semen beku sapi Madura melalui program uji keturunan. Jurnal Ilmiah Penelitian Ternak Grati. 4(1): 17-23. 